\title{
Social Initiatives in Food Consumption and Distribution as Part of Sustainable Consumption and Sharing Economy
}

\section{Katarzyna Bachnik¹, Justyna Szumniak-Samolej}

\begin{abstract}
The aim of this paper is to extract and describe recent social initiatives in food consumption and distribution in Poland and indicate their characteristics related to sustainable consumption, sharing economy and collaborative consumption and to indicate the processes, mechanisms and future development options. Food is among areas that seem to adapt to those ideas more easily which means that individual consumers seem to see value in behaving in a more responsible way. In Poland, social awareness is rather limited and responsible behavior happens on a minor scale for the moment, but more international research shows the great potential of sharing economy. Food is being wasted therefore it constitutes a good ground for changing consumption habits. The paper presents four chosen social initiatives in Poland that refer to a sustainable consumption philosophy and collaborative consumption. Those mini case studies are backed by a thorough analysis of relevant literature, theme contents on websites, and results of secondary research studies dedicated to the issues discussed in the paper. Due to the qualitative character of the study, it shall be followed by more quantitative research to allow for more general insights and conclusions.

Keywords: sustainable consumption, sharing economy, collaborative economy, social initiatives, food industry.
\end{abstract}

\section{INTRODUCTION}

Food consumption is a subject linked with numerous problems and challenges of an ethical and environmental nature. It is also marked by many contrary phenomena and food philosophies. On the one hand billions of people all over the world starve or suffer from malnutrition - about one in nine people

1 Katarzyna Bachnik, Ph.D., Hult International Business School, 1355 Sansome Street, San Francisco, CA 94109, USA; e-mail: katarzyna.bachnik@faculty.hult.edu.

2 Justyna Szumniak Samolej, Ph.D., Department of Management Theory, Warsaw School of Economics, al. Niepodległości 162, 02-554 Warsaw, Poland; e-mail: justyna.szumniak@sgh.waw.pl. 
on earth do not have enough food to lead a healthy active life (World Food Programme, 2016) - while others waste or discard uneaten food - roughly one third of the food produced in the world for human consumption every year gets lost or wasted (Food and Agriculture Organization of the United Nations, 2016). Whilst the food that is widely offered is more and more modified, processed and polluted, there are increasing numbers of people who want to consume real and worth eating food - products which are healthy, organic, coming from a well-known source and unprocessed. Whereas some choose the comfort of fast food, others hold to a slow food philosophy celebrating the process of preparing and consuming meals as well as protecting traditional and local ways of food production. Food consumption has, therefore, a cultural meaning also. As Kniazeva and Venkatesh (2007, p. 432) conclude: "food values and habits function as key cultural expressions that are central to the processes by which people establish, maintain and reinforce their (sub) cultural, ethnic, and individual identities." Philosophies and trends connected with food consumption are constantly evolving, undergoing transformations due to other social phenomena. It seems the process is progressing in the age of net technology diffusion, particularly social media, since information reaches millions of users in real time and the distance between people has definitely lessened, allowing for cooperation on an unprecedented scale. Holt (2016) says that digital crowds are currently very efficient 'innovators of culture' as they can, successfully, push forward their ideas, trends or habits to other social groups.

For these reasons, the following paper bridges a literature gap by focusing on the sustainable consumption movement, sharing economy and collaborative consumption, showing interdependencies between them, and by presenting some up-to-date mechanisms in the context of food distribution and consumption in Poland. Such an approach is understudied in Poland at the moment. The aim of the paper is to extract and describe selected ventures of sustainable consumption, sharing economy and collaborative consumption in food consumption and distribution in Poland and to indicate the processes, mechanisms and future development options. The paper addresses these issues in trying to figure out:

- What are the goals of recent social initiatives in food consumption and distribution, referring to sustainable consumption and sharing economy in Poland?

- How are they organized and what are their ways of acting (in terms of main distinguishing features)?

- How (in which areas) they refer to sustainable consumption and sharing economy? 
The structure of the paper is as follows: firstly, the concept of sustainable consumption and sharing economy is introduced so as to build a theoretical framework for the study. It is followed by a methodology introduction of the tools and approaches selected for the research. Then four case studies are highlighted so as to give evidence for tangible mechanisms and business options for sustainable consumption, sharing economy and collaborative consumption. The analysis ends with conclusions.

\section{LITERATURE REVIEW}

\section{Sustainable consumption}

Sustainable consumption is an inseparable part of corporate social responsibility (CSR), as well as sustainable development, that may be defined as 'harmonious development, compatible with a fragile balance of a global ecosystem and not entailing economy overexploitation of raw materials, and moreover, uncontrolled side effects in a social and economic field' (Mróz, 2013, p. 171; Brundtland Report, 1987). Based on 'reasonable usage of consumption of goods and an attempt to preserve a global ecosystem balance in the name of responsibility for future generations and our planets destiny' (Mróz, 2013), its existence is conditioned by consumers who present much bigger responsibility and tremendous ecology consciousness. According to McDonald et al. (2012), these are individual consumers, not governments or enterprises, who have a key role to play in meeting the targets for reduced energy consumption, more sustainable waste management practices and lifestyles with fewer environmental consequences. The consumption undertaken by private accounts of households are as high as $30 \%-40 \%$ of the economy's environmental impact. Consumers who believe that their decisions can significantly affect environmental and social issues are more likely to behave sustainably (Antonetti \& Maklan, 2014). According to Greenpeace, this type of consumer regulates their consumption needs, taking higher values into consideration (Peborgh \& Odiseo Team, 2008, p. 129). They make more informed shopping decisions, trying to learn where the products come from, and how they will be disposed. They try to reduce the negative impact of their living on the environment by reducing their consumption or by discontinuing unnecessary purchases. They perceive shopping decisions as signs of their approval or protest against particular company operations. They have a sense that by showing a good example they can make other people follow their behavior.

An effective idea of sustainable consumption introduction is determined by such variables on the consumers' side as their personality, shopping habits 
and the structure of needs. If we consider personality, it is about innate drives, learned motives and experience of the individual, which also translate into a person's motivational dispositions arising from the interaction between biological drives and the social and physical environment (Evans, Jamal \& Foxall, 2009, p. 201). We may be more inclined to follow green regulations just because we feel it is the right thing to do, while others would require additional arguments before they comply. Habits also stem out of the experience from the trial-and-error process. We learn to perform behaviors that produce positive outcomes and avoid those that yield negative outcomes. Segregating waste might be an easy habit to form unless there is reinforcement, such as lower monthly fees for garbage collection or membership of a green community. What is more, learning about habits would give clues not only about the sole act of purchasing but also of consuming and disposing of the remnants. The structure of needs, on the other hand, sheds more light on motivation and prioritizing process (Schiffman, Kanuk \& Wisenblit, 2010, p. 107). In the modern world, most consumers seek products to simultaneously satisfy various types of needs. As a result, many brands try to deliver this value. If we consider the abundance of eco-food, it aims at satisfying hunger, building health condition and caring for the environment at the same time. As research shows, the motivations of sustainable consumption include purchasing ethical alternatives, recycling, reducing personal consumption, and saving energy (Antonetti \& Maklan, 2014).

Also, the fundamental point is that growing ecology consciousness gives rise to abt. 2/3 European Union consumers who are ready to buy products marked with eco labels (the so called 'green products'). (Mróz, 2007). What is more, the consumers who actively take up a more ecological and balanced lifestyle, easily identify with the slogan: 'We can really change the world by responsible and ethical consumption' (Rok, 2009). Following the sustainable consumption track is easier due to outside factors, in relation to consumers, such as using energy-efficient and material-saving production technologies, and eliminating harmful materials in production processes. Ecology solutions tend to be at the forefront. They are heading towards usage-limiting natural environmental resources.

In conclusion, the understanding of sustainable consumption adopted in this article coincides with Sheth, Sethia and Shanthi's (2011) proposal. According to the authors, sustainable consumption can be interpreted as 'mindful consumption' that is "guided and underpinned by a mindful mindset that reflects a conscious sense of caring toward self, community and nature."

Sustainable consumption in a food area may concern a different kind of attitudes and behavior. It includes i.a., conscious food products choice taking into consideration their origin so to select organic ones coming from 
local suppliers, produced in an ecological way and socially responsible, and putting attention to eco labelling. It also covers package usage reduction and choosing the ones which are ecological. However, sustainable food consumption means limiting consumption too - not buying food overload and food waste prevention.

From the main subject perspective in this paper, the research results, having been commissioned by the European Union, indicate that barely three product categories and services cause up to $70 \%$ of the detrimental effects on the natural environment (while making merely half of the overall consumer spending). These three categories are food products, transport and construction (Mróz, 2013, p.174). As Voget-Kleschin (2014) claims food consumption proves some tension between individual lifestyles and societal consequences of such lifestyles, but asking individuals to behave more sustainably is unnecessary. Early research conducted among Polish consumers proves that the idea of sustainable consumption is not much known (Dąbrowska \& Gutkowska, 2015). Sustainable consumption behavior can be seen on a minor scale and the behavioral intensity is differentiated by socio-demographic variables and by lifestyle qualities. However, market shortages in the 1980s taught Polish consumers the value of an exchange of goods and services with others, which might turn into a sustainable habit being part of collaborative consumption in the longer term. The US market, as a mature one, proves the potential of collaborative consumption: $19 \%$ of the total US adult population has engaged in a sharing economy transaction and of those consumers who have tried sharing economy, $72 \%$ declare that they could see themselves being a consumer in the sharing economy in the next two years (PwC, 2015).

\section{Sharing economy and collaborative consumption}

Adopting an approach that sustainable consumption aims at shaping such a demand and consumer behavior, on the one hand, to meet their demands and raise life quality, and on the other hand, at the same time, to regenerate environmental capital for future generations, grassroots initiatives appearance helps promote a responsible attitude and makes an ecology procedure possible. Concomitantly with limiting usage and wastage of materials, raw materials, energy and agriculture, one needs to acknowledge it as an enabler. On the grounds of it, one can justify the statement saying that sustainable consumption and sharing economy are strongly linked. It is especially true within the food industry. Food, money, goods, services, transportation, space are among six dimensions that absorb practices, norms and behavior typical for sharing economy easily (Morgan, 2014). 
Sharing economy, also named collaborative economy, seems to gain more momentum now and as such has the power to fuel sustainable consumption or take it to the next level. It embeds a distinctive mechanism of human and physical resources sharing, in order to achieve one's goal, but it is an access to demanded products, services or resources, instead of a traditional transfer of ownership, that defines the core of this trend. As Botsman (Collaborative Consumption, 2014) defines sharing economy: It is "an economy built on a series of networks of connected individuals and communities versus centralized institutions, transforming how we can produce, consume, finance, and learn." Owyang compares sharing economy to honeycombs arguing that both are quite resilient structures that "efficiently enable many individuals to access, share and grow resources among a common group" (Morgan, 2014).

It seems that people no longer need to possess items to feel satisfied (Bardhi \& Eckhardt, 2012). They can share spare capacity and reduce costs associated with ownership. Sharing economy can be described as a new model of production and consumption that assumes "the shared creation, production, distribution, trade and consumption of goods and services by different people and organizations" (Morgan, 2014). Sharing economy rests upon the assumption that people are willing to collaborate once they see some value from the collaboration. The transactions in the system do not take the traditional form of an exchange of product or service with money; they can take the form of access such as renting, lending, subscribing, reselling, swapping, donation.

What is more, according to Botsman and Rogers (2010) people engaged in sharing must conform to four behavioral rules and principles, which are the following:

- trust between strangers, which is a must to close the deal and facilitate the exchange;

- belief in the commons, which means believing that society can secure access to goods for as much of the public as possible;

- idling capacity, as the basic observation leads to the realization that some assets might be underused, and in effect solutions to change the picture are appreciated;

- a critical mass of followers and advocates build the socio-economic system and facilitate its functioning (Bachnik, 2016).

Also, the participants' motivation of sharing economy is vital to make their engagement long-lasting and sustainable. There are several benefits that might encourage participants to join the sharing economy movement, such as:

- an opportunity of using goods, services and "experiences" for prices lower than those offered by traditional firms;

- an opportunity of using goods without a requirement to buy or own them; 
- a source of additional earnings for contractors;

- a social dimension of a given type of consumption and production (i.e., meeting new people, companionship of others, the feeling of building a community);

- added value - new experiences, feelings, "atmosphere" (i.e., atmosphere of a private home vs. an anonymous hotel room) (Szumniak-Samolej, 2016).

For some people an important advantage of the psychological nature of participating in a sharing economy is the well-being resulting from a sense of being useful, undertaking good actions (for oneself and others), which for instance, make for building a community, supporting useful initiatives, protecting the environment, 'fighting with a system', and caring for alternative (not commercial) production methods. Some researchers argue that a stronger emotional connection with the customer might be a success factor (Straker \& Wrigley, 2015).

The trend indicates that consumers are more and more active, adopt an attitude definitely entrepreneurial, on the one hand, to meet their demands, while on the other hand behave responsibly and in compliance with ethical norms they believe. Entrance barriers to a great number of markets are limited to the minimum, as well as new possibilities generated by contemporary ICT let consumers conclude agreements, form communities and create new enterprises which, directly after recruiting a critical mass of supporters, transform into successfully prospering entrepreneurs.

Thus, as took place in the case of sustainable consumption and also regarding sharing economy, one can point to outside determinants conductive to the development of 'access over ownership' approach. These factors are of a social, economic and technological nature (Mróz, 2013; European Union, 2013). Consumer mindfulness comes into mind in the first place. It results from the experience connected with the course of the latest crisis 2008-2014, which made a great many consumers tighten their belts and have a look at their budget management more carefully, strictly linked to the decrease of consumer trust in the corporate world and to the drop in the purchasing power of consumers. The growth of environmental awareness and a rising significance of digitalization expressed by the fact that consumers have become cross-channel shoppers more often and a big part of shopping are online transactions; some of the products are of a digital character. Therefore, meeting demands is not equivalent to the necessity of possessing products. In effect, the potential of the sharing economy is significant, with annual growth exceeding $25 \%$.

In addition, sharing economy seems to undergo an evolution (The next wave, 2014). It was started by companies seeking to find an easy way to share 
goods. Online classified advertisements like Craigslist started to emerge as early as 1995, followed around 2008 by rentals of homes and apartments (like Airbnb), which introduced services into the sharing economy. From 2010 it has become a multi-faceted industry that touches on nearly every aspect of everyday life, covering not only goods and services but also expertise in the form of, e.g., the marketplace for learning and teaching online (Udemy Blog, 2014).

It also needs to be put straight that sharing economy is a system in which individuals, including start-ups, who can find in this scheme an idea for a business model and traditional firms, which can conform to the conditions of this system, can operate in concomitance with each other.

Sharing economy and collaborative consumption in terms of food is quite a broad issue. The most evident way is transferring and receiving food from others. However, sharing food may take place in numerous production stages and food stages. It can deal with cost sharing and work needed to either produce or sell, transport or a production process. (Buczynski, 2013, p. 150).

\section{RESEARCH METHODS}

The study was conducted in five steps. Firstly, to identify the fundamental themes of the research and the prevailing key issues, a literature review was conducted. In the second step identification of initiatives and their selection for case studies was completed. The purposive sampling technique was considered here. The selection criteria were as follows:

1) It was assumed to focus on social initiatives. Social initiatives were defined as social ventures representing "a new type of organization that aim to create sustainable social value, such as promoting the well-being of communities and their existence is based on developing solutions to tackle complex social problems" (Jokela \& Elo, 2015).

2) To become case studies, selected initiatives should meet the sharing economy criteria according to Botsman (Collaborative Consumption, 2014) who defined sharing economy as "an economy built on a series of networks of connected individuals and communities versus centralized institutions, transforming how we can produce, consume, finance, and learn." Networks of connected individuals and communities are perceived here as grassroots social initiatives - pioneered by individuals or groups of independent legal subjects, not by formal organizations (companies or non-governmental organizations).

3) To become case studies, selected initiatives should be coherent with the following understanding of sustainable consumption: it is a 'mindful consumption' that is 'guided and underpinned by a mindful mindset that 
reflects a conscious sense of caring toward self, community and nature' (Sheth et al., 2011).

4) It was assumed that selected initiatives shall relate to food consumption and distribution, and

5) They were to be established recently (2013-2016) in Poland.

The third step was about data collection. To build case studies, online desk research, including web pages and various social media, was completed. Fourthly, the descriptive research method was used to design four initiatives which would fit the above-mentioned selection criteria. The descriptive research method was selected as the one used to "determine, describe or identify what is" (Ethridge, 2004), which we understand as describing characteristics and various aspects of the phenomenon. Agreeing on the method allowed us to arrive at the goal of the paper which is to extract and describe recent social initiatives in food consumption and distribution in Poland and to indicate their characteristics related to sustainable consumption, sharing economy and collaborative consumption.

Finally, in the fifth step, we prepared a table to organize the insights and benchmark selected initiatives which led to conclusion formulation.

\section{ANALYSIS/STUDY}

\section{Food Cooperative Good}

Food Cooperative Good is one of several food cooperatives developing dynamically in Warsaw recently. The Cooperative has been functioning since July, 2013. Originally it was an informal group which used to organize mutual shopping of healthy and organic food from local farmers. Currently it is registered as non-profit, calling 'Warsaw cooperative initiative.' The Cooperative is formed by over 170 people of different ages and various backgrounds describing their activities, using such words: 'We care for building fair and based-on-trust relationships with those who deliver food to us. We create a community accomplishing a common goal - healthy and seasonal food access produced locally, excluding a big business and the chain of corporations' agents (Kooperatywa Dobrze, 2014a). Among many other motivations to work, the members of the cooperative stress increased access to healthy, fresh and seasonal food, promotion of local farms development, winning back the influence on their vicinity, learning to cooperate in a group, grassroots democracy and forming a practical alternative for supermarkets selling low quality food, and for expensive organic shops (Kooperatywa Dobrze, 2016). 
Anyone can join the Cooperative Good. To become a member one needs to support it financially and offer a required work load. The monthly fee is 25 zlotys and a minimum required work load is 3 hours a month. The work schedule is announced for the subsequent three months, and the members declare performing goals predicted in the schedule in advance. The Cooperative work includes goods transport, organizing promotional events, doing administrative work and activity in the shop owned by the Cooperative (Kooperatywa Dobrze, 2014b).

This is the shop which distinguishes the Cooperative Good among other Warsaw food cooperatives. The shop launched in August 2014, in the center of Warsaw and is the first cooperative food shop since 1989. You can buy there healthy, organic food produced by local farmers at fair prices, that is to say, lower than in regular shops with organic shops, and moreover, organic coffee, Fair Trade chocolate, organic oils, honey, dried fruit sold by weight, sugar and gluten-free sweets and organic cosmetics together with cleaning supplies (Słowik, 2016). The shop is also a venue to conduct both educational and integration activities.

The shop is open six days a week and serves anybody who wants to do shopping there. However, there is a difference in prices for members and nonmembers. The cooperative members are entitled to lower prices, covering the price cost (Kooperatywa Dobrze, 2016b).

The shop is owned and jointly managed by all members of the cooperative. From the perspective of the shop activities, the cooperative employs only five persons in the key posts. The shop activity is not orientated to profit, the generated turnover is solely allocated to the development of the shop, cooperative and organizing activities open to social-educational enterprises.

What is worth mentioning is that the shop start-up was subsidized with the use of crowdfunding mechanisms through the Polakpotrafi.pl platform. The project was supported by 208 persons who collectively donated 15307 zlotys, while the minimum sum declared by the project author amounted to 12000 zlotys (Polakpotrafi.pl, 2016a). As research suggests, crowdfunding might be a good method of funding innovation (Kozioł-Nadolna, 2016).

The shop met with such a warm reception that in July 2016, another shop was opened in Warsaw Muranów. This time it was decided that financing would be implemented on two tracks. The first stage was to issue coupons. In the framework of 'Trust Credit' actions the coupons, having been a kind of credit, were sold - the purchase of them meant borrowing money for a new shop start-up. After January 2016, it would be possible, in one of the two Cooperative shops, to exchange the coupons for goods. The second stage of financing was a renewed crowdfunding action on Polakpotrafi.pl portal. As a result, successfully, the initial amount of 17500 zlotys was exceeded 
and $20-690$ zlotys were collected. The project was backed by 274 persons (Polakpotrafi.pl, 2016b).

The cooperative activity is based on forming and motivating cooperating communities. That is why The Cooperative Good organizes regular meetings for its members and what is more, visits to cooperating farmers. Their profiles are also presented on the cooperative's website. Furthermore, running open and educational meetings, e.g. a cooperative congress, workshops devoted to child feeding, meetings with banana planters, workshops dedicated to organic cosmetics, lectures on common food economy, etc., Facebook is used for all communication with shop clients and those who are interested in the cooperative enterprise.

The Cooperative Good is a developing, grassroots movement of aware Warsaw residents, those who are eager to get back the control of food consumed by them as well as actively influencing the reality around them. As one can read on the cooperative's website: 'food cooperatives and other grassroots enterprises are the proof that operating in an economy domain can be based on cooperation and trust, taking into consideration work conditions and caring for nature. In Poland, the rising popularity of the cooperative shows that more and more of us are feeling like organizing ourselves in a new way. We need more practical alternatives which will make the world change gradually' (Kooperatywa Dobrze, 2016a).

\section{Foodsharing Warsaw}

Foodsharing is an initiative designed to reply to the fact of wasting and throwing away food still good to eat. Foodsharing is about sharing with other people the food which is still good enough to be consumed because we have an excessive amount that is likely to be wasted or discarded. Different kind of initiatives work in foodsharing areas i.a. in Germany, Austria, Switzerland, the United States or Great Britain (Braw, 2014). Since February 2016 foodsharing has also been present in Poland.

The first foodsharing center came up in the frame of the Foodsharing Warsaw initiative. The idea behind this initiative is trivially simple - in a special place equipped with a labeled refrigerator and a cupboard anybody can leave food and simultaneously take advantage of what is left. The point is to let everybody share with others - one can add something and help oneself. There can be both readymade and homemade food. In the former case, the food should be tightly closed and described in details. (Hansen, 2016). Not only individuals are encouraged to share food but also organizations (e.g., shops, restaurants, food producers) that can transfer a surplus of food to others instead of disposing it. 
Food quality in the centers is taken care of by special guardians, called food savers. Their task is to check products shelf life and keep the fridges and shelves clean.

Currently, in the framework of Foodsharing Warsaw, three centers are working. The first one is situated at The Psychology Department of Warsaw University, the second one is in Warsaw Jazdów, and the third one in Stół Powszechny - both the café and workshop space functioning by the Powszechny Theatre in Warsaw. This initiative is also supported by its profile on Facebook where one can forward news about the latest events and foodsharing initiatives, the ways to limit food waste, and what is more, building a community consisting of those people to whom the subject is close.

Recently, Foodsharing Torun and Foodsharing Cracow opened, again created by volunteers-social activists' grassroots initiatives.

\section{FEED Them Up}

FEED Them Up is a project evolved and set in motion in March 2016, by a group of students from Warsaw School of Economics. The project was meant for the Nationwide Olympiad 'Theory Released' directed at upper-middle students and pupils, and its aim is to develop participants' practical skills in the field of project management and inspiration for social activities (Zwolnieni z Teorii, 2016). The project was created as a response to a huge problem regarding food waste in Poland, in opposition to an enormous demand for food supply by charity institutions.

Since 2013, new regulations concerning food transfers have been in force in Poland, which mean that shops, restaurants and other kinds of eateries do not pay VAT on food transferred free of charge to public benefit organizations. Previously, only food producers benefited from tax reliefs, so for others, the VAT was a cost and therefore discarding food was more profitable. Despite legal conveniences introduced a few years earlier, due to a lack of knowledge, will or logistic difficulties, not many eateries and shops decided to transfer their food surplus systematically to the most deprived.

The idea of the FEED Them Up enterprise is to employ food surpluses discarded by shops and eateries every day and transferring them to public benefit organizations for charity. The food transferring procedure is simple. FEED Them Up works as an agent, a platform connecting places which want to transfer food and organizations helping people in need.

At the beginning of the cooperation public benefit organizations inform the project representatives about a rough food amount, the sort of food (unprocessed/processed/ready meals) and a frequency the food is to be delivered (every day/ a few times a week/once a month/only after events, etc.). On this basis, a suitable place or gastronomic places are chosen to 
transfer food to a given organization caring for those who need help (Feed Them Up, 2016).

Transport responsibility, most often, is on the side of charity organizations. However, if it is troublesome, FEED Them Up is trying to contact them with the nearest gastronomic place so that the organizations' employees or their persons in charge may take the food without the necessity of using transport or select the place having transport at its disposal.

As far as donors are concerned, all gastronomic places offering food to their customers are taken into consideration, like restaurants, coffee-houses, short-order bars specializing in dairy products, bakeries, confectioner's, also hotels, small catering firms and shops. Food from gastronomic places is transferred in a free donation form. Correspondingly to public benefit organizations, at the very beginning, gastronomic places inform FEED Them Up of an indicative amount, the kind of food and frequency of transfer. The centers are selected on this basis. The conditions of donation can undergo changes at any moment of the cooperation (Feed Them Up, 2016).

The advantage of FEED Them Up cooperation with food-outlets certainly includes satisfaction at helping the needy and limiting food waste, and additionally food leftovers recycling cost-cutting. Moreover, it supports a supplementary promotion of the places, on the project social networking sites (Facebook, Instagram, YouTube), on the website, as well as ranking in media (interview arrangements, recording of promotional materials in the gastronomic places). Also, every place receives a sticker saying: 'No food waste here,' that lets the place differentiate itself from others in respect of food care (Feed Them Up, 2016).

The FEED Them Up team works basically in Warsaw. However, inhabitants of other cities make contact with it (Gdańsk, Poznań, Wrocław, Łomża or Białystok). They want to continue this initiative in their cities. Obviously they have got such a possibility, and the FEED Them Up team shares its knowledge with them and hands over indispensable documents and promotional materials, and if necessary, helps to solve difficulties.

\section{Café Fińska}

Café Fińska is an interesting example of a café - a project which was created as an artistic happening for the Zone Fresh Competition in the framework of The Grolsch ArtBoom Visual Arts Festival in 2013, presenting art in a public space of Cracow. The aim of Café Fińska was to create a meeting place for closer and less known neighbors. According to its creators, it was a reply to the specific demands of a local community. Although there are quite a few attractive cafes, restaurants and entertainment venues making unrepeatable magic local color, still the places are run traditionally, basing on economic 
calculation. However, there are not enough venues 'open to people', overstepping social divisions which engage local initiatives and their dynamic is formed by participants. The creators expected Café Fińska would fulfill the niche (Café Fińska, 2016).

For the need of the café, some space in a small tenement house was adapted. The place facilities were successfully donated. Café Fińska stands for a place open to everybody - neighbors, occasional pedestrians or tourists. The fundamental difference between this café and other Cracow places was a cash-free exchange. It meant one could have some coffee or tea but paying not with money as a means of payment, but with something the guest wished to give in return - e.g., a drawing, an interesting story, some help, a smile or drawing some pictures on a paper tablecloth. The idea was to arrange a meeting place free of financial barriers for surrounding inhabitants. The place in which a sense of community and responsibility for this site is formed. A meal and coffee were to be only a pretext for a conversation and chat. Guests' visits were made more attractive by variable activities such as board games, chess or guitar evening sessions. Each Friday varied events were organized, like concerts, exhibitions, performances, workshops (Café Fińska, 2016). Café Fińska was also open to its guests' proposals as 'the place created by people for people of every age, full of positive energy and diversities' (Polakpotrafi.pl, 2016c).

According to the creators' assumption, the Café Fińska project was supposed to function during two festival weeks. Since it met with an extremely warm welcome on the part of Cracow inhabitants, funds were successfully donated (sponsors, prizes, crowdfunding fund-raising) and prolonged its 'life.' Ultimately, in its initial place, the café worked in 2013-2015. After this time, and due to commercial rent hikes, a new venue was necessary, and at the moment, the café's activity is suspended.

\section{DISCUSSION AND CONCLUSIONS}

Buczyński (2013, p. 19) says sharing economy can reinvent our understanding of what a good citizen is. Collaborative consumption questions a previous approach to professional success, personal wealth and the sense of being an active community member which was based on money and possession of material goods. Sharing allows the creation of a new definition of value which is far from financial motivation. The reason to engage in social initiatives assumes the sharing component is mainly about increasing resource efficiency and enriching one's own and other people's lives. It is more about relationships than tasks undertaken to satisfy psychological needs. Sustainable 
consumption provides a similar effect. It supports citizenship attitude and is in favor of redefining a successful concept in professional and private dimensions of life. The motivation to commit to the greater good, personified with tangible initiatives, drives individuals and organizations to adopt socially responsible norms of behavior and to engage actively in the improvement of natural environment quality and of life quality of communities. That is why the two concepts make for a creative quest of ideas and undertaking (often grassroots ones) social and business actions based on their assumptions. For the sake of the paper, the selection of proper social initiatives was crucial so as to shed more light on the processes, mechanisms and future development options of these ventures. Table 1 . summarizes the main findings and allows for comparisons.

Table 1. Summary of main characteristics of selected social initiatives in food consumption and distribution in Poland referring to sustainable consumption and sharing economy

\begin{tabular}{|c|c|c|c|c|}
\hline & $\begin{array}{l}\text { Food Cooperative } \\
\text { Good }\end{array}$ & $\begin{array}{l}\text { Foodsharing } \\
\text { Warsaw }\end{array}$ & FEED Them Up & Café Fińska \\
\hline Creation date & 2013 & 2016 & 2016 & 2013 \\
\hline 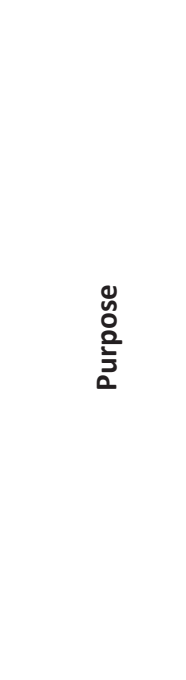 & $\begin{array}{l}\text { To create } \\
\text { a community } \\
\text { accomplishing } \\
\text { a common goal } \\
\text { - healthy and } \\
\text { seasonal food } \\
\text { access produced } \\
\text { locally, excluding } \\
\text { a big business } \\
\text { and the chain } \\
\text { of corporations' } \\
\text { agents }\end{array}$ & $\begin{array}{l}\text { To enable sharing } \\
\text { food with other } \\
\text { people to avoid } \\
\text { wasting and } \\
\text { throwing away } \\
\text { food still good } \\
\text { to eat }\end{array}$ & $\begin{array}{l}\text { In respond to } \\
\text { a massive problem } \\
\text { regarding food } \\
\text { waste in Poland, } \\
\text { in opposition to } \\
\text { an enormous } \\
\text { demand for food } \\
\text { supply by charity } \\
\text { institutions }\end{array}$ & $\begin{array}{l}\text { To arrange } \\
\text { a meeting place } \\
\text { free of financial } \\
\text { barriers for } \\
\text { surrounding } \\
\text { inhabitants. } \\
\text { To create a venue } \\
\text { 'open to people' } \\
\text { and overstepping } \\
\text { social divisions. } \\
\text { To engage } \\
\text { local initiatives } \\
\text { and encourage } \\
\text { "guests" to } \\
\text { form a sense of } \\
\text { community and } \\
\text { feel responsibility } \\
\text { for the site. }\end{array}$ \\
\hline 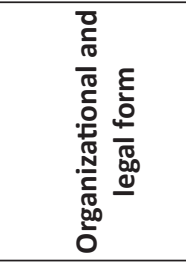 & $\begin{array}{l}\text { Originally it was } \\
\text { an informal group. } \\
\text { Currently it is } \\
\text { registered as non- } \\
\text { profit. }\end{array}$ & $\begin{array}{l}\text { Grassroots } \\
\text { initiative } \\
\text { undertaken by } \\
\text { volunteers-social } \\
\text { activists }\end{array}$ & $\begin{array}{l}\text { Project initially } \\
\text { set by a group of } \\
\text { students }\end{array}$ & $\begin{array}{l}\text { Project initially } \\
\text { created as an } \\
\text { artistic two-week } \\
\text { happening. Then, } \\
\text { prolonged thanks } \\
\text { to successful } \\
\text { fund-raising. }\end{array}$ \\
\hline
\end{tabular}




\begin{tabular}{|c|c|c|c|c|}
\hline & $\begin{array}{l}\text { Food Cooperative } \\
\text { Good }\end{array}$ & $\begin{array}{l}\text { Foodsharing } \\
\text { Warsaw }\end{array}$ & FEED Them Up & Café Fińska \\
\hline 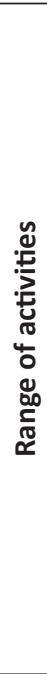 & $\begin{array}{l}\text { Organizing } \\
\text { mutual shopping } \\
\text { of healthy and } \\
\text { organic food from } \\
\text { local farmers } \\
\text { Running } \\
\text { a cooperative } \\
\text { food shop } \\
\text { Conducting } \\
\text { educational } \\
\text { and integration } \\
\text { activities }\end{array}$ & $\begin{array}{l}\text { Setting up and } \\
\text { caring for special } \\
\text { places equipped } \\
\text { with a labeled } \\
\text { refrigerator and } \\
\text { a cupboard where } \\
\text { anybody can } \\
\text { leave food and } \\
\text { simultaneously } \\
\text { take advantage of } \\
\text { what is left } \\
\text { Building } \\
\text { a community, } \\
\text { sharing } \\
\text { knowledge and } \\
\text { helping to set up } \\
\text { similar initiatives } \\
\text { in other cities }\end{array}$ & $\begin{array}{l}\text { Helping to employ } \\
\text { food surpluses } \\
\text { discarded by } \\
\text { shops and eateries } \\
\text { every day and } \\
\text { transferring them } \\
\text { to public benefit } \\
\text { organizations for } \\
\text { charity }\end{array}$ & $\begin{array}{l}\text { Running a café } \\
\text { offering drinks } \\
\text { and meals } \\
\text { Organizing, } \\
\text { concerts, } \\
\text { exhibitions, } \\
\text { performances, } \\
\text { workshops, etc. }\end{array}$ \\
\hline 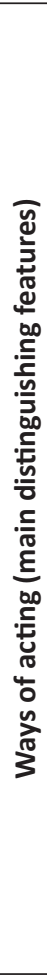 & $\begin{array}{l}\text { A food } \\
\text { cooperative } \\
\text { serving } \\
\text { cooperative's } \\
\text { members } \\
\text { Anyone can } \\
\text { join (to become } \\
\text { a member one } \\
\text { needs to support } \\
\text { it financially and } \\
\text { offer a required } \\
\text { work load) } \\
\text { The cooperative } \\
\text { shop is owned and } \\
\text { jointly managed } \\
\text { by all members of } \\
\text { the cooperative } \\
\text { The shop } \\
\text { serves anybody } \\
\text { who wants to } \\
\text { do shopping } \\
\text { there (there } \\
\text { is a difference } \\
\text { in prices for } \\
\text { members and } \\
\text { non- members }\end{array}$ & $\begin{array}{l}\text { Volunteers (called } \\
\text { food savers) take } \\
\text { after food quality } \\
\text { in the centers } \\
\text { Building and } \\
\text { supporting } \\
\text { on Facebook } \\
\text { a community } \\
\text { consisting of } \\
\text { people to whom } \\
\text { the subject } \\
\text { is close (e.g., } \\
\text { news about the } \\
\text { latest events } \\
\text { and foodsharing } \\
\text { initiatives, the } \\
\text { ways how to limit } \\
\text { food waste) }\end{array}$ & $\begin{array}{l}\text { FEED Them Up } \\
\text { works as an } \\
\text { agent, a platform } \\
\text { connecting places } \\
\text { which want to } \\
\text { transfer food and } \\
\text { organizations } \\
\text { helping people in } \\
\text { need. } \\
\text { Sharing } \\
\text { knowledge and } \\
\text { helping to set up } \\
\text { similar initiatives } \\
\text { in other cities }\end{array}$ & $\begin{array}{l}\text { A cash-free } \\
\text { exchange (not } \\
\text { with money } \\
\text { as a means of } \\
\text { payment, but with } \\
\text { something the } \\
\text { guest wished to } \\
\text { give in return - } \\
\text { e.g.,, a drawing, } \\
\text { an interesting } \\
\text { story, some help, } \\
\text { a smile, etc.) } \\
\text { Building } \\
\text { a community of } \\
\text { people who are } \\
\text { engaged and } \\
\text { responsible for } \\
\text { the venue. }\end{array}$ \\
\hline
\end{tabular}




\begin{tabular}{|c|c|c|c|c|}
\hline & $\begin{array}{l}\text { Food Cooperative } \\
\text { Good }\end{array}$ & $\begin{array}{l}\text { Foodsharing } \\
\text { Warsaw }\end{array}$ & FEED Them Up & Café Fińska \\
\hline & $\begin{array}{l}\text { The shop activity } \\
\text { is not orientated } \\
\text { to profit; the } \\
\text { generated } \\
\text { turnover is solely } \\
\text { allocated to the } \\
\text { development } \\
\text { of the shop, } \\
\text { cooperative and } \\
\text { organizing social } \\
\text { and educational } \\
\text { activities }\end{array}$ & & & \\
\hline 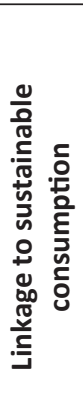 & $\begin{array}{l}\text { Healthy and } \\
\text { seasonal food } \\
\text { produced locally } \\
\text { Taking into } \\
\text { consideration } \\
\text { work conditions } \\
\text { Caring for nature } \\
\text { Motivation to } \\
\text { commit to the } \\
\text { greater good }\end{array}$ & $\begin{array}{l}\text { Enabling and } \\
\text { promoting } \\
\text { responsible and } \\
\text { conscious food } \\
\text { consumption } \\
\text { Reducing food } \\
\text { waste } \\
\text { Motivation to } \\
\text { commit to the } \\
\text { greater good }\end{array}$ & $\begin{array}{l}\text { Limiting food } \\
\text { waste by } \\
\text { gastronomic } \\
\text { places } \\
\text { Helping charities } \\
\text { (and people in } \\
\text { need) } \\
\text { Motivation to } \\
\text { commit to the } \\
\text { greater good }\end{array}$ & $\begin{array}{l}\text { Openness to } \\
\text { people and } \\
\text { overstepping } \\
\text { social divisions } \\
\text { Forming a sense } \\
\text { of responsibility } \\
\text { for the site among } \\
\text { visitors } \\
\text { Motivation to } \\
\text { commit to the } \\
\text { greater good }\end{array}$ \\
\hline 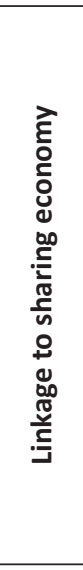 & $\begin{array}{l}\text { Cooperation, } \\
\text { trust, lack } \\
\text { of financial } \\
\text { motivation, work } \\
\text { done by members } \\
\text { to enrich their } \\
\text { own and other } \\
\text { people's lives }\end{array}$ & $\begin{array}{l}\text { Sharing food with } \\
\text { other people (for } \\
\text { free) } \\
\text { Sharing } \\
\text { knowledge } \\
\text { Work done by } \\
\text { volunteers to } \\
\text { increase resource } \\
\text { efficiency to } \\
\text { enrich their } \\
\text { own and other } \\
\text { people's lives }\end{array}$ & $\begin{array}{l}\text { Organizational } \\
\text { model in the form } \\
\text { of a platform } \\
\text { Sharing food with } \\
\text { other people (for } \\
\text { free) } \\
\text { Sharing } \\
\text { knowledge } \\
\text { Work done by } \\
\text { members to } \\
\text { increase resource } \\
\text { efficiency to } \\
\text { enrich their } \\
\text { own and other } \\
\text { people's lives }\end{array}$ & $\begin{array}{l}\text { A cash-free } \\
\text { exchange } \\
\text { Community } \\
\text { building } \\
\text { Community } \\
\text { members' } \\
\text { engagement } \\
\text { to enrich their } \\
\text { own and other } \\
\text { people's lives }\end{array}$ \\
\hline
\end{tabular}

Group shopping, the cooperative shop, work of every member for the association, cooperation based on trust, organic food, a desire for a local market and community development, offered by the Food Cooperative Good, show important aspects of the cooperative activity interacting with two trends, which are the subject of this paper. Facing everlasting promotions and widespread access to consumption goods, for many consumption community members, the effort to share food surplus with others is 
incomprehensible. This is not the case with Foodsharing Warsaw and FEED Them Up. These foodsharing believers work in the name of such values as food waste limiting or willingness to share with those who are in need. It seems to be peculiar organic work, producing small effects when it is smallscale. However, it can change a lot via education, raising social consciousness, and making solutions from this area more accessible and embedding. Apart from foodsharing support, FEED Them Up illustrates a common approach to participation in sharing economy through creating platforms. As with Uber, Blablacar, or Airbnb, FEED Them Up is a virtual 'meeting venue' - the service which connects service providers with those who want to take advantage of them. Although the trend of foodsharing is less booming in Poland than in the US and Germany, it provides a high sense of social and environmental responsibility of those who are actively engaged. Its progress in coming years will not only be a specific image of a sharing economy condition, but also pro-social and pro-ecology citizenships attitudes, particularly in an individual dimension, on a small scale, just as two illustrations from the Polish market show. In the spirit of sharing economy and sustainable consumption approach, Café Fińska is an alternative example to setting up cafes where food, its price, service quality or even the interior and 'climate' are not taken into consideration. There is something more important about it - a common property feeling and mutual responsibility for the place, building a common property and taking part in its functioning.

What is essential is that the initiatives discussed make active use of social media (e.g., crowdfunding, Facebook profile). The new media is a communication and promotion system, moreover, a cooperation platform for initiatives undertaken in the spirit of sustainable consumption and sharing economy. They make it possible to share in new ways, on a scale unavailable earlier. They ease and encourage participants to try group grassroots initiatives.

It needs to be underlined that all the described social initiatives came into existence as grassroots initiatives - originated from individuals or small groups. One of them (Food Cooperative Good), in the process of market development has changed its legal form and transformed into a formal organization (association) and another one (Café Fińska) due to commercial rent pressures is being suspended for the moment. It shows entrepreneurial spirit and the tangible need to throw into practice some values unifying more than just a few individuals. The pretty fast development of the ventures also indicates that their business models resonate well in the communities and may lead to the creation of follow-up businesses, set upon similar qualities rooted in sustainable consumption and sharing economy. Each sampling also shows a different organizational model, which provides evidence of how many different forms of operations are viable in order to adopt sustainability 
consumption and collaborative consumption notion in food consumption and distribution. Such flexibility may increase business viability for entrepreneurs.

The analyzed initiatives differ a lot in the range of undertaken activities, ways of acting and even in ways of relating to sharing economy and sustainable consumption notions. Nonetheless all of them meet the adopted study criteria of qualification to initiatives referring to sustainable consumption and sharing economy in food consumption and distribution. The biggest concern here is the sustainability of social initiatives undertaken in the food consumption and distribution sector. For the moment, being new and attractive, they sustain easily, however it is still unknown whether responsible consumption behaviors will be adopted by communities in the longer term. To verify perceptions and behavioral adoptions a more quantitative study, backed by in-depth interviews, shall be undertaken next. Its findings would also allow for more general insights and conclusions.

\section{References}

Anroinetti, P., \& Maklan S. (2014). Feelings that make a difference: How guilt and pride convince consumers of the effectiveness of sustainable consumption choices. Journal of Business Ethics, 124, 117-134.

Bachnik, K. (2016). Sustainable consumption through the sharing economy. Research Papers of Wroctaw University of Economics, 423, 35-44.

Bachnik, K. (2016). Zrównoważony rozwój a małe i średnie przedsiębiorstwa. In A. Skowronek-Mielczarek (Ed.), Zarzqdzanie małymi $i$ średnimi przedsiębiorstwami w warunkach zrównoważonego rozwoju (pp. 41-65). Warsaw, Poland: Difin.

Bardhi, F., \& Eckhardt, G. (2012). Access based consumption: The case of car sharing. Journal of Consumer Research, 39(4), 881.

Botsman, R. (2013). The sharing economy lacks a shared definition. Retrieved from http://www.collaborativeconsumption.com/2013/11/22/thesharing-economy-lacks-a-shared-definition

Botsman, R., \& Rogers, R. (2010). What's mine is yours: The rise of collaborative consumption. New York, NY: HarperCollins.

Braw, E. (2014, May). Free lunch, anyone? Foodsharing sites and apps stop leftovers going to waste. The Guardian. Retrieved from https://www. theguardian.com/sustainable-business/free-food-sharing-leftoverssurplus-local-popular

Brundtland Report (Our Common Future). (1987). United Nations World Commission on Environment and Development (WCED). Oxford, England: Oxford University Press.

Buczynski, B. (2013). Sharing is good. How to save money, time and resources through collaborative consumption. Gabriola Island, Canada: New Society Publishers. 
Café Fińska. (2016). Retrieved from http://cafefinska.wix.com/ cafefinska\#!about/c1c32

Dąbrowska, A., \& Gutkowska, K. (2015). Collaborative consumption as a new trend of sustainable consumption. Oeconomia, 14(2), 39-49.

European Union. (2013, September). Business Innovation Observatory. The sharing economy. Accessibility based business models for peerto-peer markets. Retrieved from http://ec.europa.eu/DocsRoom/ documents/13413/attachments/2/translations?locale=ro

Ethridge, D. E. (2004). Research Methodology in Applied Economics. Ames, IA: Blackwell Publishing.

Evans, M., Jamal, A., \& Foxall, G. (2009). Consumer behavior ( $2^{\text {nd }}$ ed.). West Sussex, England: Wiley.

Feed Them Up. (2016). Retrieved from http://feedthemup.com/o-projekcie

Food and Agriculture Organization of the United Nations. (2016). SAVE FOOD: Global Initiative on Food Loss and Waste Reduction. Retrieved from http:// www.fao.org/save-food/resources/keyfindings/en

Hansen, K. (2016, May). Foodsharing, czyli jedz, dziel się i kochaj! [video]. Newsweek. Retrieved from http://www.newsweek.pl/ styl-zycia/foodsharing-w-warszawie-stanela-pierwsza-w-polscejadlodzielnia,artykuly,385427,1.html

Holt, D. (2016, March). Branding in the age of social media. Harvard Business Review, Retrieved from https://hbr.org/2016/03/branding-in-the-age-ofsocial-media

Jokela, P., \& Elo, M. (2015). Developing innovative business models in social ventures. Journal of Entrepreneurship, Management and Innovation, 11(1), 103-118.

Kniazeva, M., \& Venkatesh, A. (2007). Food for thought: a study of food consumption in postmodern US culture. Journal of Consumer Behaviour, 6(6), 419-435.

Kooperatywa Dobrze. (2014a). Retrieved from http://www.dobrze.waw.pl/onas/

Kooperatywa Dobrze. (2014b). Retrieved from https://docs.google.com/file/d/ OBz2ifoflohOzSTJZQjNTcON4Z1pKMjJYQkpuRIZHbUxuaVJN/edit

Kooperatywa Dobrze. (2016a). Retrieved from http://www.dobrze.waw.pl/dlamediow

Kooperatywa Dobrze. (2016b). Retrieved from http://www.dobrze.waw.pl/onas/dolacz-do-nas (accessed 25.06.2016)

Kozioł-Nadolna, K. (2016). Funding innovation in Poland through crowdfunding. Journal of Entrepreneurship, Management and Innovation, 12(3), 7-29.

McDonald, S., Oates, C.J., Alevizou, P.J., Young, C.W., \& Hwang, K. (2012). Individual strategies for sustainable consumption. Journal of Marketing Management, 28(3-4), 445-468.

Möhlmann, M. (2015). Collaborative consumption: determinants of satisfaction and the likelihood of using a sharing economy option again. Journal of Consumer Behaviour, 14, 193-207. 
Morgan, J. (2014). Why the collaborative economy is changing everything. Forbes. Retrieved from http://www.forbes.com/sites/jacobmorgan/2014/10/16/ why-the-collaborative-economy-is-changing-everything

Mróz, B. (2007). Nowe trendy w konsumpcji a koncepcja społecznej odpowiedzialności biznesu: perspektywa europejska. In A. Dąbrowska, \& M. Janoś-Kresło (Eds.), Konsument na rynku europejskim, Warsaw, Poland: IBRKK.

Mróz, B. (2013). Konsument w globalnej gospodarce. Trzy perspektywy, Warsaw, Poland: Of. Wyd. SGH.

Panato Café. (2016). Retrieved from http://panato.org/panato-cafe

Peborgh, E., Odiseo Team. (2008). Sustainability 2.0. Buenos Aires.

Polakpotrafi.pl. (2016a). Retrieved from http://polakpotrafi.pl/projekt/sklepkooperatywy

Polakpotrafi.pl. (2016b). Retrieved from https://polakpotrafi.pl/projekt/drugisklep-kooperatywy-dobrze

Polakpotrafi.pl. (2016c). Retrieved from https://polakpotrafi.pl/projekt/cafejozefinska

PwC. (2015, April). The sharing economy. Consumer Intelligence Series. Retrieved from http://www.pwc.com/us/en/industry/entertainmentmedia/publications/consumer-intelligence-series/sharing-economy.html

Schiffman, L.G., Kanuk, L.L., \& Wisenblit, J. (2010). Consumer behaviour (10 ed). Upper Saddle River, NJ: Pearson Prentice Hall.

Sheth, J.N., Sethia, N.K., \& Shanthi, S. (2011). Mindful consumption: A customercentric approach to sustainability. Journal of the Academy of Marketing Science, 39, 21-39.

Słowik, K. (2016, July). Kooperatywa Dobrze otworzyła drugi sklep na Muranowie. Wyborcza. Retrieved from http://warszawa.wyborcza.pl/war szawa/1,34862,20384552,kooperatywa-dobrze-otworzyla-drugi-sklep-namuranowie.html?disableRedirects=true

Straker, K., \& Wrigley, C. (2015). The role of emotion in product, service and business model design. Journal of Entrepreneurship, Management and Innovation, 11(1), 11-28.

Strutyńska, J. (2014, September). Panato Cafe - płacisz za czas. Retrieved from http://www.wroclaw.pl/panato-cafe-placisz-za-czas

Szumniak-Samolej, J. (2016). Changes in the business environment. Research Papers of Wrocław University of Economics, 423, 122-137.

Szutowski, D., \& Ratajczak, P. (2016). The relations between CSR and Innovation. Model approach. Journal of Entrepreneurship, Management and Innovation, 12(2), 77-94.

Udemy. (2014). The next wave of the sharing economy [Blog post]. Retrieved from https://blog.udemy.com/the-next-wave-of-the-sharing-economy

Voget-Kleschin, L. (2015). Reasoning claims for more sustainable food consumption: A capabilities perspective. Journal of Agricultural and Environmental Ethics, 28, 455-477. 
World Food Programme. (2016). Hunger statistics. Retrieved from https:// www.wfp.org/hunger/stats

Ziferblat. (2016). Retrieved from http://www.ziferblat.co.uk

Zwiększenie konkurencyjności regionów poprzez społeczną odpowiedzialność biznesu (CSR) [Training materials]. (2012). Warsaw, Poland: PARP.

Zwolnieni z Teorii. (2016). Retrieved from http://www.zwolnienizteorii.pl/ about

\begin{abstract}
Abstrakt
Celem artykułu jest opisanie ostatnich inicjatyw społecznych w obszarze konsumpcji i dystrybucji żywności w Polsce i wskazanie ich cech zwiqzanych ze zrównoważonq konsumpcjq, ekonomiq współdzielenia oraz konsumpcjq współpracujqcq. Dodatkowym celem jest także wskazanie procesów, mechanizmów i przyszłych ścieżek rozwoju dla tego typu inicjatyw. Żywność to obszar, w którym implementacja wyżej wymienionych zjawisk wydaje się łatwiejsza, gdyż konsumenci dostrzegaja znaczenie swoich odpowiedzialnych wyborów. Jednak $w$ Polsce, świadomość społeczna $w$ tym zakresie jest raczej ograniczona, a zachowania odpowiedzialne występuja na małq skalę. Natomiast badania międzynarodowe wskazuja na duży potencjał gospodarki współdzielenia, także w obszarze żywności. Marnotrawstwo żywności jest dobrym punktem wyjścia do zmiany nawyków konsumpcyjnych. $W$ artykule przedstawiono cztery wybrane inicjatywy społeczne z Polski, które realizujq filozofię zrównoważonej i współpracujqcej konsumpcji. Z uwagi na jakościowy charakter studium, następnym etapem będq badania ilościowe pozwalajq̨ce na wysunięcie bardziej generalnych wniosków.
\end{abstract}

Słowa kluczowe: zrównoważona konsumpcja, ekonomia współdzielenia, ekonomia współpracujqca, inicjatywy społeczne, przemysł spożywczy.

\title{
Biographical notes
}

Katarzyna Bachnik, Ph.D., is an expert with 10-year experience in management, innovation and design thinking, international marketing, corporate social responsibility and social media. She has worked as a lecturer, a trainer and an editor and she is an author of several publications and expertise papers in the aforementioned areas. Affiliated at Institute of Management, Warsaw School of Economics, she has been granted several international scientific scholarships.

Justyna Szumniak-Samolej, Ph.D., is an Assistant Professor at Department of Management Theory, Warsaw School of Economics, Poland. Her key research areas are corporate social responsibility, social media and new business models. She participated in several research projects primarily focused on social corporate responsibility in the age of digital networked technologies. Her corporate social responsibility academic publications include books, refereed journal articles, book chapters and refereed conference papers. 